\title{
Inadvertent left internal mammary artery (LIMA): great cardiac vein anastomosis
}

\author{
Matthew Lumley, Alice Booker, Brian Clapp
}

Department of Cardiology, St Thomas' Hospital, London, UK

\section{Correspondence to} Dr Matthew Lumley, mattlumley@doctors.org.uk
To cite: Lumley $M$, Booker A, Clapp B. BMJ Case Rep Published online: [please include Day Month Year] doi:10.1136/bcr-2012007450

\section{DESCRIPTION}

A 70-year-old man was transferred due to progressive angina with a history of severe aortic valve stenosis and multivessel coronary artery disease treated with biological aortic valve replacement and two-vessel coronary artery bypass surgery (CABG) 1 year previously. A recent myocardial perfusion scan was positive for reversible ischaemia in the left anterior descending artery (LAD) territory. Invasive coronary angiography revealed moderate stenosis in the left main stem, a significant lesion in the proximal LAD and a small nondominant left circumflex with moderate disease. The dominant right coronary artery (RCA) was severely diseased (figure 1). The saphenous vein graft to the RCA was found to be patent. The inadvertent left internal mammary artery (LIMA) graft was anastomosed to the great cardiac vein (GCV), and contrast was seen passing through the GCV and draining into the coronary sinus (figure 2; video 1). Transthoracic echocardiogram (TTE) and the right heart catheter revealed $\mathrm{Q}_{\mathrm{p}}: \mathrm{Q}_{\mathrm{s}}$ of 1.1:1 and normal right heart volume. He was treated with drug eluting stent percutaneous coronary intervention to the proximal LAD with good symptomatic relief. The iatrogenic arteriovenous fistula was managed conservatively and will be followed up with serial TTEs.

There are over 20 reported cases of iatrogenic arteriovenous fistula. ${ }^{12}$ Presenting symptoms predominantly relate to ischaemia in the territory of the

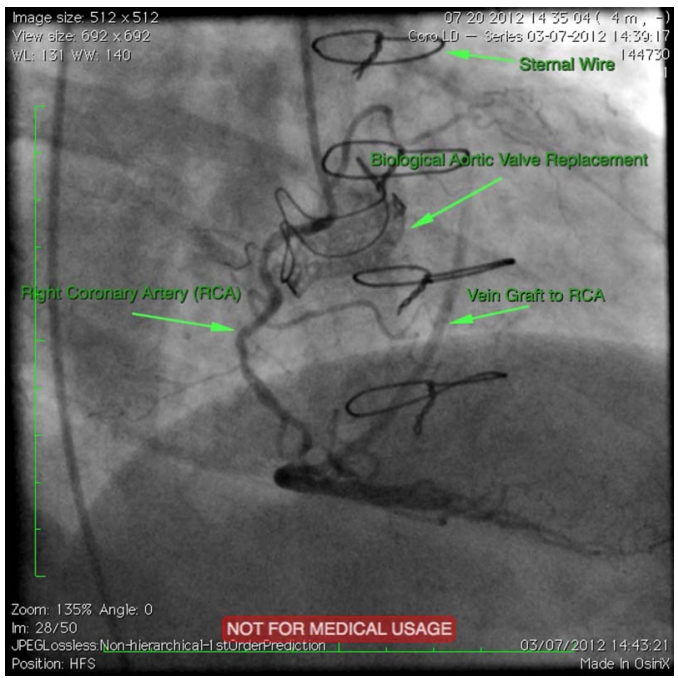

Figure 1 Still image of an invasive coronary angiogram. The right coronary artery (RCA) has been engaged with a Judkins Right 4 Catheter. The RCA is severely diseased along its entire course. The sapheneous vein graft anastomosed to the RCA is also visible on this image. Sternotomy wires and previous biological aortic valve replacement are highlighted.

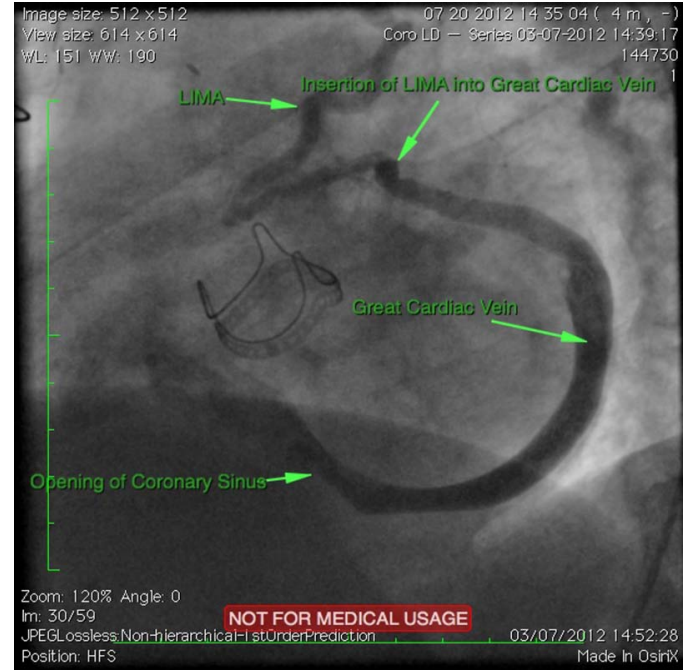

Figure 2 Still image of an invasive coronary angiogram. The distal end of the inadvertent left internal mammary artery (LIMA) is anastomosed to the great cardiac vein. The insertion point is shown. Contrast can be seen to drain into the coronary sinus.

ungrafted artery and include angina, dyspnoea, volume overload and ventricular arrhythmia. ${ }^{1}$ Volume overload of the right heart is a common finding in congenital fistula but has not been reported in iatrogenic cases.

Inadvertent anastomosis of the LIMA to the GCV is a rare complication of CABG. Treatment should

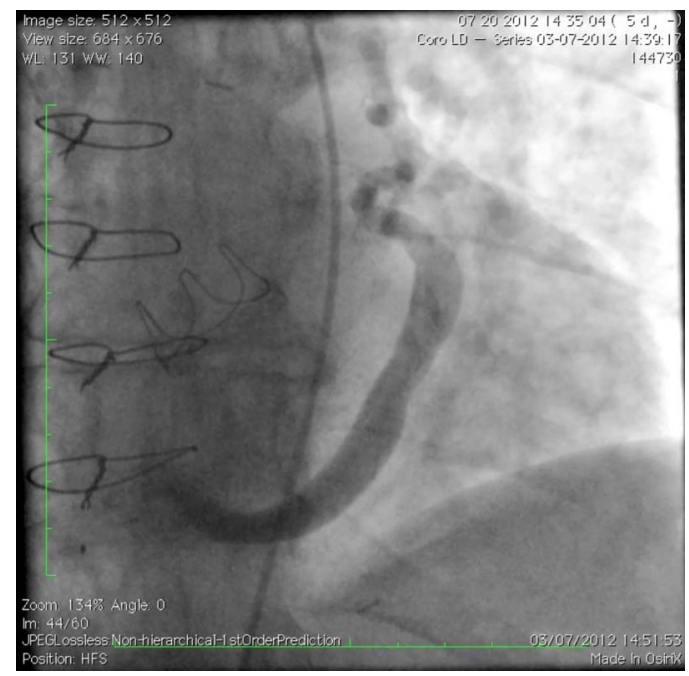

Video 1 An internal mammary artery (IMA) catheter is engaged in the left internal mammary artery (LIMA). Contrast can be seen to be opacifying the patent LIMA. The LIMA has been grafted to the great cardiac vein (GCV) and contrast is seen filling the GCV and draining into the coronary sinus. 
depend on the patient's symptoms and the severity of left to right shunting or development of right ventricular volume overload. Management can be conservative or, by occlusion, percutaneously with vascular plugs and embolisation coils, and if this is not possible, by surgery.

Competing interests None.

Patient consent Obtained.

Provenance and peer review Not commissioned; externally peer reviewed.

\section{REFERENCES}

1 Calkins JB, Talley D, Kim N. latrogenic aorto-coronary venous fistula as a complication of coronary artery bypass surgery: patient report and review of the literature. Catheter Cardiovasc Diagn 1996;59:55-9.

2 Jung IS, Jeong J-O, Kim SS, et al. latrogenic left internal mammary artery to great cardiac vein anastomosis treated with coil embolization. Korean Cir J 2011:41:105-8.

Copyright 2013 BMJ Publishing Group. All rights reserved. For permission to reuse any of this content visit http://group.bmj.com/group/rights-licensing/permissions.

BMJ Case Report Fellows may re-use this article for personal use and teaching without any further permission.

Become a Fellow of BMJ Case Reports today and you can:

- Submit as many cases as you like

- Enjoy fast sympathetic peer review and rapid publication of accepted articles

- Access all the published articles

- Re-use any of the published material for personal use and teaching without further permission

For information on Institutional Fellowships contact consortiasales@bmjgroup.com

Visit casereports.bmj.com for more articles like this and to become a Fellow 